\title{
PENGEMBANGAN PERANGKAT PEMBELAJARAN FISIKA BERBASIS \\ REACT SEBAGAI IMPLEMENTASI K13 UNTUK MEMFASILITASI KEHETEROGENEN GAYA BELAJAR SISWA SMA/MA DI KOTA BANDAR LAMPUNG
}

\author{
Novi Ayu Kristiana Dewi, Bernadhita Herindri Samodera Utami \\ Program Studi Sistem Informasi, Fakultas, STMIK Pringsewu \\ Email: noviayudi@gmail.com
}

Diterima: 1 September 2020 Disetujui: 22 September 2020

\begin{abstract}
Abstrak
Tujuan dari penelitian ini adalah untuk mengembangkan perangkat pembelajaran berupa modul fisika berbasis REACT yang dapat memfasilsitasi keheterogenan gaya belajar siswa di kelas. Metode penelitian yang digunakan Research \& Development (R\&D) dengan empat tahap 4-D, yaitu define, design, develop, dan disseminate. Hasil penelitian diperoleh bahwa modul pembelajaran yang dikembangkan valid dengan kategori baik pada komponen materi dan sangat baik pada komponen media. Penerapan modul pembelajaran yang dikembangkan efektif untuk meningkatkan hasil belajar siswa pada kategori sedang. Penyebaran modul mendapatkan respon yang sangat baik dari guru-guru fisika SMA/MA. Dengann demikian perangkat pembelajaran yang dikembankan layak untuk digunakan.

Kata Kunci: perangakat pembelajaran fisika, REACT, gaya belajar.
\end{abstract}

\begin{abstract}
The purpose of this research is to develop a learning tool. It is a physics module REACT based which can facilitate heterogeneity of student learning styles in class. The research method used is Research \& Development $(R \& D)$ with four stages 4-D, namely define, design, develop, and disseminated. The results showed that the learning module developed was valid with good categories in the material component and very good in the media component. The application of the developed learning module was effective to improve student learning outcomes in the moderate category. The distribution of the module got a very good response from physics teachers. Thus the learning device developed is feasible to use.
\end{abstract}

Keywords: physics learning tools, REACT, learning style

\section{PENDAHULUAN}

Penyempurnaan pola pikir dalam pengembangan kurikulum 2013 antara lain: pembelajaran harus berpusat pada peserta didik, interaktif, secara jejaring, menggunakan pendekatan sains, belajar secara kelompok, berbasis multimedia, pengembangan potensi peserta didik, multidiscipline, dan pembelajaran kritis. Oleh karena itu, tujuan 
Dewi., Utami.- Pengembangan Perangkat Pembelajaran Fisika ...

pendidikan nasional pada pelaksanaan kurikulum 2013 dapat terwujud dengan memberikan kesempatan kepada siswa untuk terlibat aktif dalam pembelajaran. Keberadaan guru dalam proses pembelajaran adalah sebagai pengatur, pengorganisasi, pembimbing dan sekaligus partner. Proses pembelajaran dapat berjalan optimal apabila guru dapat menerapkan strategi pembelajaran secara arif dan bijaksana sesuai dengan kebutuhan dan keadaan siswa maupun sekolah. Salah satu keadaan siswa yang menjadi pertimbangan dalam pemilihan strategi pembelajaran adalah gaya belajar. Untuk mencapai keberhasilan proses pembelajaran maka setiap gaya belajar harus diapresiasikan dengan mempersiapkan model dan strategi pembelajaran yang tepat dari pendidik sehingga transfer of knowledge dapat terlaksanan dengan baik (Noer, 2016).

Sebuah penelitian melaporkan bahwa pemilihan strategi pembelajaran yang tidak sesuai dengan gaya belajar siswa di kelas menyebabkan tidak terfasilitasinya sebagian besar siswa dalam proses pembelajaran sehingga tujuan belajar tidak dapat tercapai (Dewi \& Riswanto, 2019).

Gaya belajar merupakan kombinasi dari cara seseorang dalam menyerap informasi, kemudian mengatur dan mengelola informasi tersebut (Deporter \& Hernacki, 2015). Berdasarkan kemampuan otak, gaya belajar dibagi menajdi tiga kategori, yaitu: visual belajar melalui apa yang dilihat, auditorial belajar melalui apa yang didengar, dan kinestetik belajar melalui gerak dan sentuhan (Windura, 2015).

Pembelajaran fisika pada kurikulum 2013 menuntut penerapan strategi pembelajaran yang bersifat kontekstual karena pengetahuan tidak dipindahkan begitu saja dari guru ke peserat didik. Pembelajaran harus memberikan kesempatan kepada peserta didik untuk terlibat aktif mengontruksi pengetahuannya sehingga dapat memahami, menerapkan, memecahkan masalah, dan menemukan ide-ide baru lewat pengetahuan yang diperolehnya. Salah satu strategi pembelajaran kontekstual yang dapat ditawarkan dalam pembalajaran fisika adalah REACT. Crawford, (2001) 
Dewi., Utami.- Pengembangan Perangkat Pembelajaran Fisika ...

menyatakan bahwa REACT akan meningkatkan mutu

merupakan pembelajaran kontekstual

yang terdiri dari lima komonen yang

bersifat relating (mengaitkan),

experiencing (mengalami), applying

(menerapkan), cooperating (bekerja sama),

dan

transferring

(mentransver). Pembelajaran REACT

menekankan bahwa belajar bukan

sekedar menghafal, tetapi

merekonstruksikan atau membangun pengetahuan dan keterampilan baru lewat fakta-fakta yang mereka alami dalam kehidupan nyata, sehingga siswa diberi kesempatan untuk lebih berperan aktif dalam kegiatan belajar (Dewi, Aminah, \& Sukarmin, 2015). Informasi yang akan disampaikan dalam pembelajaran REACT dikaitkan dengan informasi yang sudah diketahui oleh peserta didik sehingga akan lebih mudah memahami konsep-konsep baru yang akan dipelajari (Fakhruriza \& Kartika, 2015).

Selain pemilihan strategi pembelajaran yang tepat maka guru harus menyiapkan perangkat pembelajaran sebagi wujud kesiapan proses belajar mengajar. Peningkatan mutu perangkat pembelajaran juga pembelajaran dengan baik (Sahidu, Gunawan, Rokhmat, \& Rahayu, 2018). Penggunaan perangkat pembelajaran dalam pembelajaran sains dapat meningkatkan penguasaan siswa terhadap kosep-konsep yang dipelajari secara efektif (Listyawati, 2012).

Salah satu perangkat pembelajaran adalah media ajar. Media ajar atau media pembelajaran merupakan sarana dan prasarana pendudukung untuk menunjang pembelajaran di kelas (Taufiq, Dewi, \& Widiyatmoko, 2014). Media pembelajaran berupa modul dirancang dan dibuat sebagai sumber belajar atau bahan ajar bagi siswa maupun guru untuk membantu dalam proses mencapai tujuan belajar (Somantri, 2015). Keuntungan dari penerapan modul pembelajaran adalah menumbuhkan motivasi belajar (Peniati, 2012). Selain itu penggunaan modul juga dapat meningkatkan hasil belajar dan membantu siswa untuk belajar mandiri (Rosa, 2015).

Hasil observasi di lapangan menunjukkan bahwa guru fisika di SMA/ MA di Bandar Lampung belum 
Dewi., Utami.- Pengembangan Perangkat Pembelajaran Fisika ...

memanfaatkan penggunaan perangkat pembelajaran yang sesuai dengan karakter siswa di kelas. Sebagian besar guru belum memanfaatkan modul pembelajaran fisika sebagai bahan ajar. Hampir semua guru menyatakan bahwa di dalam pembelajaran tidak memperhatiakan gaya belajar siswa di kelas. Oleh karena itu, dalam penelitian ini dikembangkan sebuah perangkat pembelajaran berupa modul fisika berbasis REACT untuk memfasilitasi keheterogenan gaya belajar siswa dengan fokus materi pembelajaran fluida statis. Modul fisika berbasis REACT diharapkan dapat membantu guru dan siswa SMA/MA melakukan pembelajaran Fisika secara kontekstual dengan menggunakan bahan ajar yang tepat agar semua gaya belajar dapat tervasiliatasi dengan baik.

\section{METODE}

Penelitian ini merupakan penelitian pengembangan untuk meghasilkan suatu produk dan melakukan pengujian keefektifan terhadap produk tersebut dalam bidang pendidikan atau yang dikenal dengan Educational Research and Development (R\&D). Adapun produk yang dihasilkan dalam penelitian ini adalah perangkat pembelajaran berupa modul pembelajaran fisika berbasis REACT pada materi fluida ststis untuk memfasilitasi keheterogenen gaya belajar siswa di kelas.

Model pegembangan yang digunakan dalam penelitain ini adalah model Thiagarajan yang terdiri dari empat tahap yang dikenal dengan 4D, yaitu: define (pendifinisian) berupa analisis kebutuhan, design (perancangan) dengan merancang draft perangkat pembelajaran berupa modul, develop (pengembangan) dengan melakukan validasi yang dilanjutkan uji coba produk, dan disseminate (penyebaran) melakukan penyebaran terhadap produk yang dihasilkan untuk mendapatkan respon.

\section{HASIL DAN PEMBAHASAN}

Tahap awal dari penelitian ini adalah define (pendefinisian). Tujuan dari pendefinisian adalah untuk memunculkan masalah mendasar yang diperlukan untuk 
Dewi., Utami.- Pengembangan Perangkat Pembelajaran Fisika ...

mengembangkan perangkat pembelajaran (Hartono \& Noto, 2017). Tahap pendefnisian dilakuakn melalui studi literatur, studi lapangan, dan analisis persyaratan pendesainan modul (Yanti, Kuswanto, Habibi, \& Kinasih, 2020).

Materi fiska yang dipilih dalam penelitian ini adalah fluida statis. Alasan pemilihan fluida statis karena terdapat banyak konsep yang berkaitan dengan kehidupan seharihari, selain itu siswa dapat melakukan berbagai percobaan sederhana bahkan membuat alat sederhana serta mempresentasikannya sehingga aktiviatas belajar seperti visual, auditorial, dan kinestetik dapat terlaksanakan. Pada tahap ini peneliti menyebarkan angket untuk mengetahui gaya belajar siswa serta angket pengungkap kebutuhan guru dan siswa terkait pembelajaran fisika materi fluida statis.

Berdasarkan hasil angket gaya belajar dari sekitar 130 siswa SMA/MA yang tersebar di kota Bandar Lampung memiliki gaya belajar yang heterogen, yaitu 38\% siswa memiliki gaya belajar visual, $42 \%$ memiliki gaya belajar auditorial, dan $20 \%$ siswa memiliki gaya belajar kinestetik. Selanjutnya berdasarkan angket pengungkap kebutuhan guru terhadap enam guru fisika SMA/MA di Kota Bandar Lampung diperoleh informasi bahwa sebagian besar guru tidak memperhatikan gaya belajar siswa di kelas sehingga perangkat pembelajaran yang digunakan belum sesuai dengan kebutuhan siswa yang heterogen. Sedangkan berdasarkan angket pengungkap kebutuhan siswa diperoleh informasi bahwa masih ada siswa yang mengalami kesulitan belajar karena hanya memanfaatkan buku teks, siswa tidak terlibat dalam kegiatan eksperimen, sebagian besar dari siswa harus mencari bahan lain karena tidak semua guru menyiapkan modul pembelajaran secara khusus. Selanjutnya baik guru atau siswa menyatakan setuju jika dikembangkan perangkat pembalajaran berupa modul fisika berbasis REACT untuk memfasilitasi keheterogenan gaya belajar siswa di kelas sehingga siswa dapat mengoptimalkan kegiatan belajarnya sesuai dengan cara masing-masing.

Langkah kedua dari pengemabangan ini adalah design. 
Dewi., Utami.- Pengembangan Perangkat Pembelajaran Fisika ...

Tahap ini bertujuan untuk merancang modul pembelajaran fisika (Wati, 2015). Modul yang dikembangkan terdiri dari pendahuluan, inti, dan penutup. Jumlah kegiatan pembelajaran dalam modul juga disesuaikan dengan jumlah pertemuan pada satu kompetensi dasar yang telah ditentukan.

Pembelajaran yang dikehendaki dari modul ini adalah pembelajaran kontekstual yang mampu melibatkan semua gaya belajar siswa. Pada pembelajaran kontekstual siswa dihadapkan pada peristiwa dalam kehidupan sehari-hari yang berkaitan dengan konten materi yang diajarakan (Sambada, 2012). Pembelajaran kontekstual yang diterapkan dalam modul yang dikembangkan adalah REACT. REACT adalah strategi pembelajaran yang tidak hanya mengajarkan konsep dan fakta tetapi mengarahkan siswa untuk menemukan makna dalam pembelajaran melalui kegiatan mengaitkan konsep dengan kehidupan sehari-hari (Cahyono, Sutarto, \& Mahardika, 2017). Sehingga modul yang dirancang juga mengikuti Langkah-langkah pembelajaran
REACT seperti: relating, experiencing, applying, cooperating dan transferring. Setiap Langkah pembelajaran memiliki simbol khusus pada modul berupa gambar yang mencerminkan kegiatan tersebut.

Relating disajikan di bagian awal setiap bab pada modul pembelajaran. Pada kegiatan ini disajikan sebuah gambar dengan narasi dan sejumlah pertanyaan agar siswa mengaitkan fenomena alam yang sering dijumpai dalam kehidupan sehari-hari. Setelah siswa menyadari bahwa fenomena yang pernah ditemui adalah bagian dari pembelajaran fisika maka dilanjutkan pada penanaman konsep baru. Setelah siswa menerima konsep baru maka langkah selanjutnya adalah experiencing, pada tahap ini siswa melakukan kegiatan percobaan secara berkelompok agar siswa mengalami sendiri tentang konsep yang dipelajari dengan cara bekerja sama (cooperating). Selanjutnya siswa dapat mengaplikasikan konsep tersebut untuk menyelesaikan permasalan berupa soal-soal fisika realistik yang dapat dilakukan secara kerja sama pada tahap applying. Tahap terakhir dari pembelajaran ini 
Dewi., Utami.- Pengembangan Perangkat Pembelajaran Fisika ...

adalah transferring, yaitu siswa deskripsi modul, cara penggunaan mentransfer atau memindahkan modul, mind map, daftar isi, materi pengetahuan atau konsep yang sudah diperolehnya ke dalam kehidupan sehari-hari atau ke dalam konsep baru. Contoh kegiatan transferring pada pembelajaran ini berupa pemanfaatan konsep fluida statis untuk mengukur tekanan udara di suatu tempat dengan memanfaatkan peralatan sederhana. Dengan penerapan pembelajaran REACT diharapkan semua siswa dengan berbagai gaya belajar dapat terlibat aktif dalam pembelajaran.

Hasil dari tahap perancangan ini diperoleh draft modul fisika berbasis REACT pada materi fluida statis yang terdiri dari cover, kata pengantar, prasyarat, kegiatan pembelajaran satu sampai tiga, rangkuman, evaluasi, glosarium, kunci jawaban, dan daftar pustaka.

Setelah modul selesai dirancang maka tahap selanjutnya adalah develop (pengembangan). Pada tahap ini draft 1 modul dikembangkan dan dilakukan evaluasi hingga akhirnya dapat dilakukan uji coba pada produk (Wijayanti \& Sungkono, 2017).

Tahap pengembangan dimulai dengan uji validasi modul oleh dua dosen pendidikan fisika dan dua guru fisika SMA/MA di Kota Bandar Lampung. Hasil validasi disajikan pada tabel 1 dan 2 .

Tabel 1. Saran Validator pada Komponen Materi

\begin{tabular}{|c|c|c|}
\hline No. & Aspek Penilaian & Saran Perbaikan \\
\hline 1. & $\begin{array}{l}\text { Keterpahaman peserta } \\
\text { didik terhadap pesan }\end{array}$ & $\begin{array}{l}\text { - } \quad \text { Gunakan kalimat yang lugas dan tidak ambigu pada } \\
\text { narasi kegiatan relating di pembalajaran } 1 .\end{array}$ \\
\hline 2. & Keakuratan materi & $\begin{array}{l}\text { - Soal-soal latihan harus lengkap agar bisa diselesaikan } \\
\text { oleh siswa. } \\
\text { - Penulisan rumus pada contoh-contoh soal perlu di cek } \\
\text { lagi. } \\
\text { - Penulisan satuan perlu di cek lagi }\end{array}$ \\
\hline 3. & $\begin{array}{l}\text { Konsistensi sistematika } \\
\text { dan penggunaan istilah }\end{array}$ & $\begin{array}{l}\text { - Penggunaan simbol gaya apung harus konsisten antara } F_{a} \\
\text { atau } F_{A} \\
\text { - Pilih penggunaan kata "pengisap" atau "piston" }\end{array}$ \\
\hline 4. & Ketepatan bahasa & $\begin{array}{l}\text { - } \quad \text { Bedakan penggunaan istilah hisdrostatis dan hidrostatika. } \\
\text { - } \mathrm{ROH} \text { alkohol dan roh nyawa berbeda, bedakan agar siswa } \\
\text { tidak salah paham. }\end{array}$ \\
\hline
\end{tabular}


Dewi., Utami.- Pengembangan Perangkat Pembelajaran Fisika ...

Peneliti melakukan perbaikan baik, dari guru 1 sebesar 3,27 dengan komponen materi sesuai saran dari kategori sangat baik, dan dari guru 2 validator. Berdasarkan validasi pada komponen materi diperoleh skor ratarata dari dosen 1 sebesar 3,30 dengan kategori sangat baik, dari dosen 2 sebesar 3,43 dengan kategori sangat sebesar 3,00 dengan kategori baik. Sehingga hasil validasi pada komponen materi diperoleh skor ratarata akhir sebesar 3,25 dengan kategori baik.

Tabel 2 Saran Validator pada Komponen Media

\begin{tabular}{|c|c|c|}
\hline No. & Aspek Penilaian & Saran Perbaikan \\
\hline 1. & Desain kulit modul & $\begin{array}{ll}\text { - } & \text { Gunakan ilustrasi pada sampul yang lebih menarik. } \\
\text { - } & \text { Sampul harus menampilkan pusat pandang yang lebih baik } \\
\text { lagi. }\end{array}$ \\
\hline 2. & Desain Isi modul & 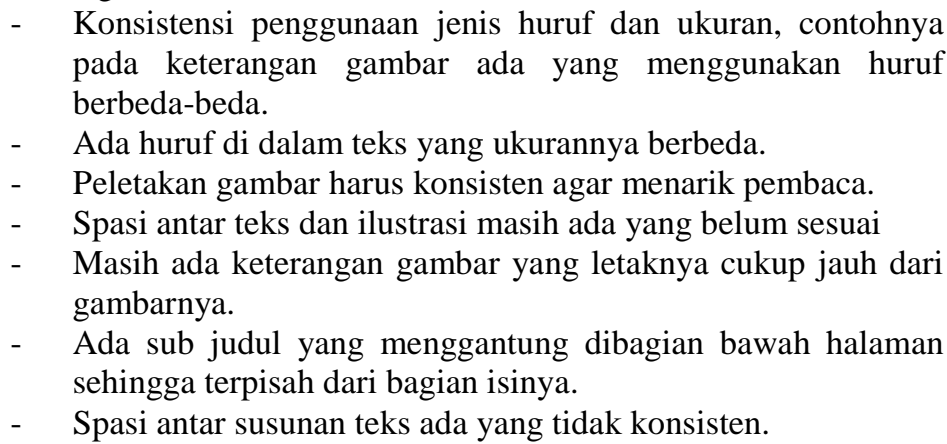 \\
\hline
\end{tabular}

Peneliti melakukan perbaikan modul pada komponen media sesuai dengan saran dari validator. Hasil validasi dari komponen media diperoleh skor rata-rata dari dosen 1 sebesar 3,73 dengan kategori sangat baik, dari dosen 2 sebesar 3,48 dengan kategori sangat baik, dari guru 1 sebesar 3,24 dengan kategori baik, dan dari guru 2 sebesar 3,21 dengan kategori baik. Sehingga hasil akhir validasi pada komponen media diperoleh skor rata-rata sebesar 3,42 dengan kategori sangat baik.

Setelah draft 1 modul pembelajaran dilakukan validasi dan perbaikan maka diperoleh draft 2 . Selanjutnya dilakukan uji coba pada kelompok kecil yang terdiri dari sembilan siswa SMAN 14 Bandar Lampung. Dari uji coba kecil ini siswa diberi angket keterbacaan dan respon terhadap modul pembelajaran yang dikembangkan. Dari hasil angket keterbacaan siswa pada uji 
Dewi., Utami.- Pengembangan Perangkat Pembelajaran Fisika ...

coba kecil diperoleh data bahwa semua siswa menyatakan modul yang dikembangakn memiliki tampilan yang menarik, tulisan dapat dibaca dengan jelas, bahasa yang digunakan mudah dipahami, dapat membantu siswa memahami materi pembelajaran, dan gambar yang digunakan juga dapat mendukung pemahaman siswa terhadap konsep fisika. Selanjutnya dari angket respon siswa diperoleh data bahwa $77,78 \%$ siswa memberikan respon baik dan $22,22 \%$ siswa memberikan respon sangat baik. Berdasarkan perolehan skor akhir rata-rata respon siswa diperoleh 3,25 dengan kategori baik. Pada uji coba kecil ini masih ditemukan kesalahan dalam pengetikan tulisan, sehingga dilakukan perbaikan terlebih dahulu dan diperloleh draft 3 modul. Selanjutnya modul dicetak ulang dalam jumlah yang lebih banyak untuk dilakukan uji coba pada kelas besar.

Uji coba modul kelas besar dilakukan pada kelas XI Mia 7 di SMAN 14 Bandar Lampung. Sesuai dengan pembelajaran kontekstual maka siswa dibuat dalam kelompok- kelompok kecil. Sebelum kegiatan pembelajaran di mulai, peneliti menyebarkan angket gaya belajar di kelas tersebut dan diperoleh data bahwa siswa di kelas XI Mia 7 memiliki gaya belajar heterogen yang terdiri dari $41,46 \%$ siswa memiliki gaya belajar visual; 46,34\% siswa memiliki gaya belajar auditorial; dan $12,20 \%$ siswa memiliki gaya belajar kinestetik. Pengelompokan gaya belajar tersebut merupakan gaya belajar dominan yang dimiliki oleh siswa, bukan berarti siswa hanya menggunakan satu gaya belajar saja. Namun gaya belajar yang paling dominan merupakan cara yang paling disukai oleh siswa karena belajar akan menjadi lebih mudah dengan cara tersebut (Papilaya \& Huliselan, 2016). Gaya belajar berkaitan dengan karakteristik belajar siswa dalam menyerap, mengolah dan menyampaikan informasi (Sari, 2014). Hasil dari sebuah penelitian menunjukkan bahwa ada interaksi antara pemilihan strategi pembelajaran dengan gaya belajar (Siagian, 2012). Oleh karena itu, guru harus pandai menetukan strategi pembelajaran agar semua gaya belajar 
Dewi., Utami.- Pengembangan Perangkat Pembelajaran Fisika ...

siswa dapat terfasilitasi dengan baik. belajar siswa disajikan pada tabel 3 di Adapun keterkaitan komponen bawah ini.

pembelajaran REACT dengan gaya

Tabel 3. Keterkaitan Komponen REACT dengan Gaya Belajar Siswa

\begin{tabular}{|c|c|c|}
\hline No. & Komponen REACT & Aktivitas pada Setiap Gaya Belajar \\
\hline 1. & Relating & 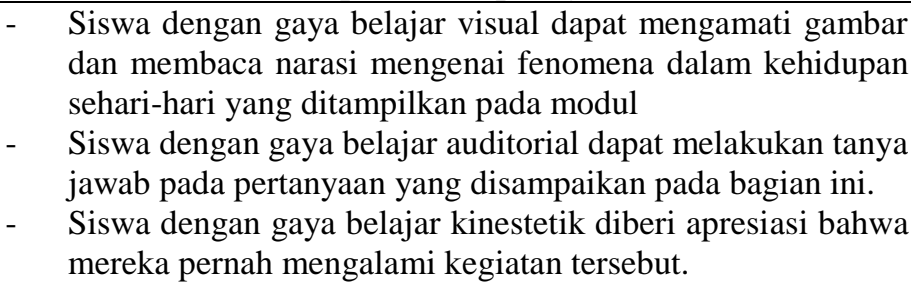 \\
\hline 2. & Experiencing & $\begin{array}{l}\text { - Siswa dengan gaya belajar visual dapat membaca secara } \\
\text { seksama panduan atau prosedur percobaan yang disajikan } \\
\text { pada modul untuk melakukan eksperimen. } \\
\text { - Siswa dengan gaya belajar auditorial mempunyai } \\
\text { kesempatan untuk dapat mempresentasikan hasil } \\
\text { percobaannya. } \\
\text { Siswa dengan gaya belajar kinestetik mempunyai } \\
\text { kesempatan untuk dapat melakukan percobaan secara } \\
\text { langsung. }\end{array}$ \\
\hline 3. & Applying & $\begin{array}{l}\text { - Siswa dengan gaya belajar visual mampu membaca soal } \\
\text { atau gambar dengan baik dan menuliskan simbol-simbol } \\
\text { atau persamaan untuk menyelesaikan masalah. } \\
\text { - Siswa dengan gaya belajar auditorial memeiliki kesempatan } \\
\text { untuk bertanya dengan temannya atau membatu temannya } \\
\text { yang mengalami kesulitan karena pembelajaran dilakukan } \\
\text { secara berkelompok. } \\
\text { Siswa dengan gaya belajar kinestetik memiliki kesempatan } \\
\text { untuk mencoba menyelesaikan soal-soal fisika dengan } \\
\text { bimbingan temannya. }\end{array}$ \\
\hline 4. & Cooperating & $\begin{array}{l}\text { - Pembelajatran dilalukan secara berkelompok sehingga } \\
\text { siswa dapat saling bekerja sama antara pelajar visual, } \\
\text { auditorial, dan kinestetik. Kegiatan belajar secara } \\
\text { berkelompok menjadikan siswa untuk saling melengkapi. }\end{array}$ \\
\hline 5. & Transferring & $\begin{array}{l}\text { - Pelajar visual dapat memindahkan pengetahuan yang } \\
\text { diperoleh setelah pembelajaran kedalam pengetahuan baru } \\
\text { melalui membaca atau mencari informasi di internet. } \\
\text { Pelajar auditorial dapat melaukan kegiatan transferring } \\
\text { dengan lebih banyak bertanya atau mencari informasi baru } \\
\text { melalui youtube. } \\
\text { Pelajar kinestetik dapat melakuakn kegiatan transferring } \\
\text { dengan memanfaatkan konsep-konsep yang telah dipelajari } \\
\text { untuk dipraktekkan dalam kehidupan nyata. }\end{array}$ \\
\hline
\end{tabular}

Berdasarkan tabel 3 di atas dapat

memfasilitasi keheterogenan gaya

diketahui bahwa dengan penerapan belajar siswa, karena setiap gaya

pembelajaran REACT dapat belajar memiliki kesempatan untuk 
Dewi., Utami.- Pengembangan Perangkat Pembelajaran Fisika ...

terlibat aktif dalam pembelajaran. pembelajaran dan menerapkan Kesalahan pemilihan strategi konsep-konsep yang diperolehnya pembelajaran juga akan berpengaruh untuk menciptakan peralatan terhadap hasil belajar siswa. Seperti sederhana (Dewi et al., 2015). hasil penelitian yang dilaporkan oleh Dewi \& Riswanto (2019) bahwa penerapan strategi pembelajaran ekspositori dalam suatu kelas yang didominasi oleh siswa dengan gaya belajar kinestetik menyebabkan ketidak berhasilan ketuntasan belajar secara klasikal.

Keefektifan dari penerapan perangkat pembelajaran fisika berbasis REACT dalam penelitian ini dapat diketahui dari peningkatan $N$ gain score sebesar 0,51 dengan kategori sedang. Hasil yang sama juga ditunjunkkan oleh Purnamasari, Annur, \& Salam (2016) bahwa bahan ajar dengan model REACT efektif untuk meningkatkan pemahaman konsep fisika. Dalam penelitian lainnya dilaporkan bahwa pembelajaran dengan menggunakan modul fisika berbasis REACT tidak hanya meningkatkan hasil belajar siswa, tetapi juga dapat meningkatkan kecerdasan majemuk dan kreativitas siswa, karena siswa diberi kesempatan untuk terlibat aktif dalam Dengan demkian, pemilihan strategi pembelajaran yang tepat dengan memperhatikan keheterogenan gaya belajar siswa akan menghasilkan tujuan belajar yang optimal.

Tahap terakhir dari penelitian ini adalah disseminate yaitu menyebarkan perangkat pembelajaran yang dikembangkan kepada beberapa guru fisika SMA/MA di Kota Bandar Lampung. Hasil dari tahap penyebaran ini diperoleh nilai ratarata sebesar 3,33 yang artinya perangkat pembelajaran yang dikembangakn mendapatkan respon yang sangat baik dari guru Fisika SMA/MA di Kota bandar Lampung.

\section{KESIMPULAN DAN SARAN}

\section{Kesimpulan}

Berdasarkan hasil penelitian dapat disimpulkan bahwa pengembangan perangkat pembelajaran berupa modul fisika berbasis REACT dikembangkan melalui empat tahap, yaitu define, design, develop, dan disseminate. 
Dewi., Utami.- Pengembangan Perangkat Pembelajaran Fisika ...

Modul pembelajaran yang dikembangkan dinyatakan valid dengan kategori baik pada komponen materi dan sangat baik pada komponen media. Modul fisika berbasis REACT efektif untuk meningkatkan hasil belajar fisika siswa terhadap penguasaan konsep dengan kategori sedang. Hasil penyebaran produk mendapatkan respon dengan kategori sangat baik. Oleh karena itu, modul pembelajaran fisika berbasis REACT layak digunakan sebagai bahan ajar pada siswa dengan berbagai gaya belajar.

\section{Saran}

Saran untuk guru agar dalam pemilihan strategi pembelajaran selalu memperhatikan kebutuhan siswa di kelas, terutama mengenali gaya belajar siswa di kelas agar materi pelajaran yang disampaikan dapat diterima dengan baik oleh semua siswa. Dalam pelaksaan pebelajaran guru juga harus melibatkan berbagai aktivitas agar setiap gaya belajar siswa terfasilitasi.

\section{DAFTAR PUSTAKA}

Cahyono, B. A. D., Sutarto, S., \&
Mahardika, I. K. (2017). Model Pembelajaran REACT (Relating, Experiencing, Applying, Cooperating, Transfering) disertai Media Video Kejadian Fisika Terhadap Keterampilan Proses Sains dan Hasil Belajar Siswa dalam Pembelajaran Fisika di SMA. Jurnal Edukasi, 4(3), 20-24.

Crawford, M. L. (2001). Teaching Contextual: Research, Rationale and Tachniques for Improving Student Motivation and Achievement in Mathematics and Sciences. Texas: CCI Publishing.

Deporter, B., \& Hernacki, M. (2015). Quantum Learning: Membiasakan Belajar Nyaman dan Menyenangkan, ed. ke 1. In Terjemahan: Alwiyah Abdurrahman \& Sari Meutia. Bandung: Kaifa.

Dewi, N. A. K., Aminah, N. S., \& Sukarmin, S. (2015). Pengembangan Modul Fisika Berbasis Relating, Experiencing, Applying, Cooperating, and Transferring (React) Pada Materi Alat Optik Untuk Meningkatkan Kecerdasan Majemuk Dan Kreativitas Siswa. INKUIRI: Jurnal Pendidikan IPA, 4(2), 47-56.

Dewi, N. A. K., \& Riswanto, R. (2019). Analisis Penerapan Strategi Pembelajaran Ekspositori terhadap Prestasi Belajar Fisika Ditinjau dari Gaya Belajar Siswa. Jurnal Riset Dan Kajian Pendidikan Fisika, 6(1), 17-22.

Fakhruriza, O., \& Kartika, I. (2015). Keefektifan model pembelajaran 
Dewi., Utami.- Pengembangan Perangkat Pembelajaran Fisika ...

relating, experiencing, applying, cooperating, transferring (REACT) untuk meningkatkan hasil belajar siswa SMP pada materi kalor. Jurnal Riset Dan Kajian Pendidikan Fisika, 2(2), 54-57.

Hartono, W., \& Noto, M. S. (2017). Pengembangan modul berbasis penemuan terbimbing untuk meningkatkan kemampuan matematis pada perkuliahan kalkulus integral. JNPM (Jurnal Nasional Pendidikan Matematika), 1(2), 320-333.

Listyawati, M.

(2012). Pengembangan perangkat pembelajaran IPA Terpadu di SMP. Journal of Innovative Science Education, 1(1).

Noer, U. (2016). Analisis Gaya Belajar Mahasiswa terhadap Model dan Strategi Pembelajaran Dosen. AL-ISHLAH: Jurnal Pendidikan Islam, 14(2).

Papilaya, J. O., \& Huliselan, N. (2016). Identifikasi gaya belajar mahasiswa. Jurnal Psikologi, 15(1), 56-63.

Peniati, E. (2012). Pengembangan modul mata kuliah strategi belajar mengajar IPA berbasis hasil penelitian pembelajaran. Jurnal Pendidikan IPA Indonesia, 1(1).

Purnamasari, P., Annur, S., \& Salam, A. (2016). Pengembangan bahan ajar melalui model pembelajaran react pada materi elastisitas. Berkala Ilmiah Pendidikan Fisika, 4(3), 209-221.

Rosa, F. O. (2015). Pengembangan modul pembelajaran IPA SMP pada materi tekanan berbasis keterampilan proses sains. Jurnal Pendidikan Fisika, 3(1).

Sahidu, H., Gunawan, G., Rokhmat, J., \& Rahayu, S. (2018). Pengembangan Perangkat Pembelajaran Fisika Berorientasi Pada Kreativitas Calon Guru. Jurnal Pendidikan Fisika Dan Teknologi, 4(1), 1-6.

Sambada, D. (2012). Peranan kreativitas siswa terhadap kemampuan memecahkan masalah fisika dalam pembelajaran kontekstual. Jurnal Penelitian Fisika Dan Aplikasinya (JPFA), 2(2), 37-47.

Sari, A. K. (2014). Analisis Karakteristik Gaya Belajar VAK (Visual, Auditorial, Kinestetik) Mahasiswa Pendidikan Informatika Angkatan 2014. Edutic-Scientific Journal of Informatics Education, 1(1).

Siagian, S. (2012). Pengaruh Strategi Pembelajaran dan Gaya Belajar terhadap Hasil Belajar IPA. Jurnal Teknologi Pendidikan, 5(01), 193-208.

Somantri, D. W. (2015). Pelaksanaan Pembelajaran Menggunakan Media Modul di Sekolah Dasar Negeri 8 Banjar Kota Banjar Patroman. E-Jurnal Skripsi Program Studi Teknologi Pendidikan.

Taufiq, M., Dewi, N. R., \& Widiyatmoko, A. (2014). Pengembangan Media Pembelajaran Ipa Terpadu Berkarakter Peduli Lingkungan Tema "Konservasi" Berpendekatan ScienceEdutainment. Jurnal Pendidikan 
Dewi., Utami.- Pengembangan Perangkat Pembelajaran Fisika ...

IPA Indonesia, 3(2), 122575.

Wati, W. (2015). Pengembangan Modul Pembelajaran Fisika SMA Terintegrasi Penanggulangan Bencana Tanah Longsor. Jurnal Ilmiah Pendidikan Fisika Al-Biruni, 4(1), 109-119.

Wijayanti, S., \& Sungkono, J. (2017). Pengembangan Perangkat Pembelajaran mengacu Model Creative Problem Solving berbasis Somatic, Auditory,
Visualization, Intellectually. AlJabar: Jurnal Pendidikan Matematika, 8(2), 101-110.

Windura, S. (2015). Be An ABsolute Genius. Jakarta: Gramedia.

Yanti, F. A., Kuswanto, H., Habibi, H., \& Kinasih, A. (2020). Development of Analogy-Based Material Physics Module to Provide Analogy Ability of Physics Teachers Candidates. Jurnal Pendidikan Fisika Indonesia, 16(1), 34-40. 